\title{
2013s-18
}

\section{Corporate Reputation and Social Media: A Game Theory Approach}

\author{
Thierry Warin, Nathalie de Marcellis-Warin, William Sanger, \\ Bertrand Nembot, Venus Hossein Mirza
}

\begin{tabular}{c}
\hline Série Scientifique \\
Scientific Series
\end{tabular}

\section{Montréal}

Juillet 2013

(C) 2013 Thierry Warin, Nathalie de Marcellis-Warin, William Sanger, Bertrand Nembot, Venus Hossein Mirza. Tous droits réservés. All rights reserved. Reproduction partielle permise avec citation du document source, incluant la notice $($ ).

Short sections may be quoted without explicit permission, if full credit, including (C) notice, is given to the source.
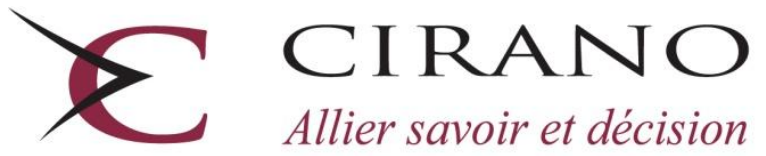

Allier savoir et décision

Centre interuniversitaire de recherche en analyse des organisations 


\section{CIRANO}

Le CIRANO est un organisme sans but lucratif constitué en vertu de la Loi des compagnies du Québec. Le financement de son infrastructure et de ses activités de recherche provient des cotisations de ses organisations-membres, d'une subvention d'infrastructure du Ministère du Développement économique et régional et de la Recherche, de même que des subventions et mandats obtenus par ses équipes de recherche.

CIRANO is a private non-profit organization incorporated under the Québec Companies Act. Its infrastructure and research activities are funded through fees paid by member organizations, an infrastructure grant from the Ministère du Développement économique et régional et de la Recherche, and grants and research mandates obtained by its research teams.

\section{Les partenaires du CIRANO}

\section{Partenaire majeur}

Ministère de l'Enseignement supérieur, de la Recherche, de la Science et de la Technologie

Partenaires corporatifs

Autorité des marchés financiers

Banque de développement du Canada

Banque du Canada

Banque Laurentienne du Canada

Banque Nationale du Canada

Banque Scotia

Bell Canada

BMO Groupe financier

Caisse de dépôt et placement du Québec

Fédération des caisses Desjardins du Québec

Financière Sun Life, Québec

Gaz Métro

Hydro-Québec

Industrie Canada

Investissements PSP

Ministère des Finances et de l'Économie

Power Corporation du Canada

Rio Tinto Alcan

State Street Global Advisors

Transat A.T.

Ville de Montréal

\section{Partenaires universitaires}

École Polytechnique de Montréal

École de technologie supérieure (ÉTS)

HEC Montréal

Institut national de la recherche scientifique (INRS)

McGill University

Université Concordia

Université de Montréal

Université de Sherbrooke

Université du Québec

Université du Québec à Montréal

Université Laval

Le CIRANO collabore avec de nombreux centres et chaires de recherche universitaires dont on peut consulter la liste sur son site web.

Les cahiers de la série scientifique (CS) visent à rendre accessibles des résultats de recherche effectuée au CIRANO afin de susciter échanges et commentaires. Ces cahiers sont écrits dans le style des publications scientifiques. Les idées et les opinions émises sont sous l'unique responsabilité des auteurs et ne représentent pas nécessairement les positions du CIRANO ou de ses partenaires.

This paper presents research carried out at CIRANO and aims at encouraging discussion and comment. The observations and viewpoints expressed are the sole responsibility of the authors. They do not necessarily represent positions of CIRANO or its partners. 


\title{
Corporate Reputation and Social Media: A Game Theory Approach
}

\author{
Thierry Warin ${ }^{\dagger}$, Nathalie de Marcellis-Warin ${ }^{*}$,William Sanger ${ }^{\S}$, \\ Bertrand Nembot ${ }^{* *}$, Venus Hossein Mirza ${ }^{\dagger \dagger}$
}

\section{Résumé / Abstract}

Corporate reputation is more and more the most valuable asset for a firm. In this day and age, corporate reputation, although an intangible asset, is and will grow as the most essential asset to publicize and also protect. Social media are a formidable tool to publicize a firm's brand and improve its reputation. However, it can also be deadly. Associated with social media comes the "buzz", i.e. the means to spread at an unprecedented speed and scale any information, being true or false. In this paper, our aim is to propose a Game Theory approach with both a finite and an infinite horizon. The model presented here helps us evaluate the impact of social media on a firm's reputation. It also highlights the important parameters of a firm's reputation in this new digital era.

Mots clés/keywords : social media, social economics, brand tribalism, corporate reputation.

Codes JEL: L14; M14; M21; M31

\footnotetext{
${ }^{*}$ We would like to thank CIRANO and the GMT Lab (Polytechnique Montréal) for their support. Our thanks go to the participants of the IAES and IT\&FA conferences (Montreal, 2013) and the IFBAE conference (Tours, 2013); the usual caveats apply.

${ }^{\dagger}$ HEC Montréal, Vice-President at CIRANO, warint@ cirano.qc.ca.

$\$$ Polytechnique Montréal, Vice-President at CIRANO.

${ }^{\S}$ Polytechnique Montréal and CIRANO.

** Polytechnique Montréal and CIRANO.

${ }^{\dagger}$ Polytechnique Montréal and CIRANO.
} 


\section{Introduction}

Five hundred million messages are sent everyday on Twitter. If one considers a message from a Chinese fortune cookie to be as long as a tweet (140 symbols), then these tweets represent more than 2500 tons of crispy dough. Daily. Twitter is just one example, and we can add Facebook, Google+, LinkedIn, etc. The multiplication of social networks is at the origin of the often-cited "buzz". The exponential replication and amplification of information is of paramount importance for firms in this day and age. Reputation is and will be the most valuable asset of a firm. Paradoxically, a firm's reputation is defined as an intangible asset, since we do not know how to measure it. In this digital age, at once, firms' reputation is more and more important, and also more and more exposed through the buzz created on social media (De MarcellisWarin and Teodoresco, 2012).

Our primary goal in this paper is twofold: (1) to highlight the relevant research on building, measuring, and managing brand equity in social media times and (2) to propose a game theoretic approach to represent the reputation concept. Since the important works of Milgrom (1981), Fudenberg and Kreps (1986), Milgrom and Roberts (1980), economists have well understood the value of brand equity. Before these works though, it was impossible to capture what branding was all about. Branding and reputation were concepts already used extensively in marketing but not in economics. Since then, micro-economists specializing in industrial organization have built new approaches based on the first seminal works aforementioned. Reputation was seen as a barrier to entry or a strategy used by companies to gain some market power.

This is even more interesting in the context of social media. Information can be (1) a true fact or it can be (2) a pure hoax. The nature of the informant has also changed: before, only customers would call the company, nowadays even someone on the other side of the globe can post a comment on a company that does not even sell products in his/her country. Beyond the quality of information and the informant, the pace has also changed. Whatever the time of the day or the day of the year, a company's reputation is exposed to any true issue written by a customer in any random country or even to any random hoax that seems funny or that is assumed to be too-big-to-be-wrong and, eventually, that becomes viral. The high pace of the information transmission (true or false) has an impact on the company's reputation with an unprecedented magnitude. Needless to say that social media have also become a strategic weapon against competitors. It is no surprise that the terminology "viral" comes from the virus/anti-virus software industry. With the advent of social media, consumers - and non-consumers - are able to comment on any product, any supplier, or any strategic decision made by a company. The "buzz" created by social media has an impact on firms' reputation. And when a company is public, a proxy of this impact can be the variation of the stock price right after the buzz. It is thus interesting to use the stock price and its correlation with the buzz to see how deep the impact was on reputation, how long it will take to recover the initial level of reputation, etc.

Most social media websites offer the option of "send this to a friend". For instance, on Facebook and Twitter we have the option of "share on Facebook" or "share on Twitter". YouTube offers "email this video," as well as the ability to link the video to Facebook, Twitter, Buzz, Myspace, orkut, hi5, tumblr, Bebo, Blogger, and StumbleUpon (Veil et al., 2011). Social media and their convolutions create the perfect foundation for any information to go viral. Instead of the old two-step flow from message creator to group members, the transmission model for viral communication is a "networked, distributed flow, and via disordered and disorganized yet patterned ways, to combine the communication format, the communication technology, and the social contact" (Bennett, 2003). 
In recent years, we have witnessed reputation crises, which are the result of viral information - real, or not - spread via social media websites. As an example, we could refer to KFC-Taco Bell rats incident that happened in New York: the story of rats running at the Greenwich restaurant was first reported on early morning TV news by local station WNBC-TV. ${ }^{1}$ The related video was uploaded online on February 23 , 2007 and, according to a Technorati search, more than 1,000 blogs spread the story and thousands discussed the story (Mei et al., 2010). Social media websites bring people together on a platform where they are able to share information and exchange their ideas. In the KFC-Taco Bell incident, the most popular video on YouTube received 2,644 responses sparking comments such as "No more KFC for me" and "When a business allows for such rodents to run freely, the message to us consumers is consumers come last" (Mei et al., 2010). The video of the KFC-Taco Bell incident is still available on the Internet. Once information has been uploaded in cyber space, it will stay there for an unlimited period of time, unless the owner chooses to take it down.

Another example illustrating how information can become viral in social media is Nestlé's case, which happened on March 17, 2010. The environmental group Greenpeace has long been putting pressure on Nestlé to stop using palm oil. In 2010, for the first time Greenpeace used the social media to attack the giant food company. Greenpeace launched an online campaign accusing Nestlé of buying palm oil for its popular chocolate bar Kit Kat from an Indonesian supplier that clears vast areas of Indonesian forest for its plantations. The consequence of this deforestation is that it destroys the natural habitat of the endangered orang-utans. The campaign included a 60-second video of an office worker enjoying a Kit Kat which, rather than being the popular chocolate bar, appears to be a chocolate-covered ape finger. As the worker eats the treat, it oozes blood over his chin, shocking his co-workers. ${ }^{2}$ The video clip ended with a play on Kit Kat's famous slogan: "Have a break? Give orang-utans a break."” Nestlé attempted to censor the video and, as a result, the social media attack spread even more on the company's Facebook page, which was inundated with negative comments and requests to stop using palm oil. Nestlés Facebook team responded to their fans' comments by threatening to delete comments left by individuals using modified versions of their corporate logo. This added fuel to the fire. ${ }^{4}$ The criticism did not end up on Facebook, it spilled over on Twitter. Negative Twitter comments related to Nestlé's palm oil appeared every 15 minutes. At the end, it was not just social media, also the press picked up the story and publications in The Economist, Guardian and Wall Street Journal appeared. Nestlé's social media crisis caused the public relations storm, the reputational damage and the financial losses from reduced sales and the fall in its share price. $^{5}$

Similar cases are on the rise as social media usage is becoming more popular nowadays. Another example is the Domino's YouTube hoax that happened on April 2009: Domino's pizza employees videotaped their joke, which was about contaminating sandwiches and pizza by violating health-code standards and performing unsanitary acts, and shared their deed on YouTube. The video went viral and the media picked up the story. The crisis happened for Domino in a short period of time. Social media has an unprecedented ability to create and disseminate hoaxes and rumors (Veil et al., 2011); in fact, "hoaxes and rumors are more provoking in cyberspace" (Heath and Millar, 2004). For a message to go viral, the content must be provocative enough to engage unpaid receivers to spread the information through their social network (Porter et al., 2006). As a "sick joke," the Domino's YouTube video was provocative enough to go viral (Veil et al., 2011). The crisis resulted in crime charges for the two employees, more than a million

1 Rats at Taco Bell and KFC. Retrieved from: http://www.churchofthecustomer.com/blog/2007/02/rats_at_taco_be.html 2 Kit Kat spat goes viral despite Nestlé's efforts. Retrieved from: http://www.theglobeandmail.com/report-on-business/kit-katspat-goes-viral-despite-nestls-efforts/article 1503795/?cmpid=1

3 Greenpeace, Nestlé in battle over Kit Kat viral. Retrieved from:

http://www.cnn.com/2010/WORLD/asiapcf/03/19/indonesia.rainforests.orangutan.Nestlé/index.html

4 http://www.techguerilla.com/Nestlé-facebook-greenpeace-timeline-in-proces

5 Nestlé and Facebook: flashmob fail? Retrieved from: http://www.zdnet.com/blog/howlett/Nestlé-and-facebook-flashmobfail/ 1887 
disgusted viewers and a major company facing a public relations crisis. ${ }^{6}$ Initially, Domino's replied to this reputation crisis by posting an apologetic video on YouTube and addressed the crisis directly via social media.

\section{Review of the literature}

In what follows, we will review some relevant articles on what constitutes a brand, what determines a firm's reputation, and the impact of social media on a firm's reputation. We do not pretend to be exhaustive, but we will review the literature that will help us funnel our argument to better understand our research question.

\subsection{Branding}

The "Brand" aggregates what is referred to as (1) product brand and (2) corporate brand, according to Knox and Bickerton (2003). The product brand concept, which takes its roots in the marketing field, can be defined as "a product or service, which a customer perceives to have distinctive benefits beyond price and functional performance". Behind the product brand concept, we find the management activities, which lead to the selection of a product brand in order to create some economic value to the company: its corporate brand. The corporate brand concept goes beyond the product itself and it concerns directly the organization through its different stakeholders. To deepen the definition of corporate brand, Chun (2005) distinguishes the corporate brand concept (also referred to as the image of a company) from the reputation concept (defined in the next section): the brand concept refers to "how others see us" or "simply the impressions or perceptions held by external stakeholders" (Bromley, 1993).

The public's perception of a company makes a difference on a competitive market: a better perception of a company's brand can create a competitive advantage in the long run in order to strengthen or gain some new market shares (Park et al., 1986). Brand enhancement can be achieved through positioning strategies developed during the 60s (Maggard, 1976), such as head-on positioning, or positioning with an idea or positioning for social accountability. Maggard qualifies positioning as a "warmed-over" version of market segmentation, brand and product differentiation.

Moreover, in order to enhance one's brand, Park et al. (1986) proposed a brand concept management, which is structured around sequential steps: (1) selecting a brand concept (product brand), (2) introducing the brand concept in the marketplace, (3) elaborating the brand concept (positioning strategies focused mainly on enhancing the value of the brand), and finally (4) fortifying the brand concept by linking it to other products to reinforce it. It is only through successful brand concepts that a company will be able to strengthen its own corporate brand. However, for a new entrant, whose brand is unknown on a certain market and product quality is similar to the dominant firm's, Dröge et al. (1987) suggest that the implementation of an associative strategy with a popular brand (co-branding) can achieve fast and accurate product positioning.

Brand management is one aspect of companies' concerns toward brand enhancement. The second aspect is the assessment of their brands: how brand equity can be assessed? Keller et al. (2006) mentioned that the brand equity, which refers to the quantification of the benefits attached to the corporate brand, can be observed through three different points of view: (1) customer-based, (2) company-based and (3) financebased. On the customer level, the brand equity can be captured by five criteria: awareness, associations, attitudes (or attraction), attachment and activity (sales). On the company level or product market level,

6 Video Prank at Domino's Taints Brand. Retrieved from:

http://www.nytimes.com/2009/04/16/business/media/16dominos.html?_r=0 
brand equity can be assessed through price differences between the company and its competitors and also through products' sales volumes. Finally, on the financial market level, brand equity can be assessed through financial market performance.

\subsection{Reputation}

Economists have tried for several decades to capture the concept of reputation. Among them, a quartet formed by Milgrom, Roberts, Kreps, and Wilson have developed, in the early 80s, a game theoretical approach to understand the actions of firms within this context.

According to Milgrom and Roberts (1980), an established firm will target any new entrant in order to build its reputation of a strong incumbent. This leads future entrants to anticipate a predatory strategy from the incumbent. The emergence of reputation could be explained by two reasons: information asymmetries in the market and repeated actions with possibility to observe past behaviors.

In multi-period games, players may decide early in the game to build up their reputation. Adding imperfect information about the players' payoffs to the model developed by Selten (1974), Kreps and Wilson (1981) illustrated the power of reputation in finitely repeated games. Reputation will influence the firms' behavior. In their work, two models are presented: in the first game, they describe a multi-market monopolist with potential entrants, which are uncertain about the monopolist's payoffs. This one-sided uncertainty leads to a unique equilibrium where the entrants nearly elude challenging the monopolist because of the fear of a predatory response. The second model takes into account the uncertainty about the entrant's payoffs. This second game leads to a price war between players since all of them have a reputation to protect.

This seminal work from the four authors (Kreps, Milgrom, Roberts, and Wilson, 1982) confirms the essential role played by imperfect information on reputation. Since decisions are impacted by past actions, monopolists and new entrants will be affected by their behavior. If a monopolist ever declines to fight an entrant, it will be considered as weak. If an entrant ever fails to enter the market, it will be revealed as weak. As a consequence, a strong monopolist always secures its market (by predation), whereas a strong entrant is always able to enter the market.

The authors see reputation as a synonym for predictions of the opponents' future strategies. This concept is used for a dominant firm to ensure its ability to avoid long-term opportunity losses by contracting short-run costs, especially against multiple opponents (Fudenberg and Kreps, 1986).

Following the quartet's work, Mailath (2007) investigates the effect of reputation in repeated games between players. The author describes the reputation effect as "the impact upon the set of equilibriums of perturbing [a] game by introducing incomplete information of a particular kind".

However, Chun (2005) has identified the difficulty of clearly defining reputation, as a concept used in several disciplines (accounting, economics, marketing, organizational behavior, sociology, strategy (Fombrun and van Riel, 1997). Her paper examines the construct of corporate reputation on the one hand and, on the other hand, the construct of image and of identity. She defines identity as "how we see ourselves", image as "how others see us" and desired identity as "how we want others to see ourselves". Corporate reputation is an "umbrella construct", built upon these three core elements, referring to the "cumulative impressions of internal and external stakeholders". This definition is also cited by Brammer and Pavelin (2004) who have linked corporate social responsibility activities of a firm with its reputation. In their article, Building a Good Reputation, they enlighten a previous definition of reputation as "a perceptual representation of a company's past actions and future prospects that describe the firm's overall appeal to all its key constituents when compared to other leading rivals"; it also "represent(s) publics' cumulative judgments of firms over time" (Charles J. Fombrun, 1996). 
Reputation has been conceptualized in Game Theory as a signal from a firm. Building on its own reputation, a company has the choice to try new avenues using its brand name in order to convince its customers (Cabral, 2000). He identifies three effects to this decision: (1) a direct reputation effect by which the customers will be influenced by the firm's reputation; (2) a feedback reputation effect, by which the new products sales will influence the base traditional products sold by the company; and (3) a signaling effect, by which a firm will only stretch its reputation if it is confident enough in its higher quality.

Moreover, reputation is not only a differentiating criterion between companies, but can also be seen as strength. Rodrigues, Souza, and Leitão (2009) treat reputation as a strategic asset for firms. One can benefit from another's reputation, and thus a synergy can emerge through co-branding: shared costs, exposure and risks; market penetration; increasing sales... With a Game Theory approach, they illustrated the concept of co-branding between Apple and Nike through their Nike+ product, and how nerdy and sporty consumers were both successfully reached. With a wider scope, Choi and Jeon (2007) capture co-branding and reputation as a signaling process in order to establish a new firm as a high-quality product player.

\subsection{Reputation and social media}

Monitoring the social Web has become a strategy for firms in order to reach their customers. Stavrakantonakis et al. (2012) have illustrated the approach to adopt in relation to social media monitoring tools. With more than 200 available monitoring tools, it is possible for firms to access the "real customers' opinions, complaints and questions at real time in a highly scalable way". They listed and described several commercial tools (such as Alterian-SM2, Brandwatch, Converseon, Cymfony-Maestro, evolve24-Mirror, Meltwater-Buzz, NM Incite-My BuzzMetrics, Radian6, Sysomos, Visible Technologies-Visible Intelligence), but also free available tools (Addict-o-matic, Boardreader, Google Alerts, HyperAlerts, Klout, Netvibes, Twazzup, WhosTalkin and Yahoo Pipes).

Jones et al. (2009a) explore the problematic aspects of Web 2.0 from a firm's point of view: how to best interact with consumers? Since the social Web has brought speed, reach and interactivity between firm and stakeholders, a need for some procedure exists in order to take full advantages of the Web 2.0 (and avoid potential threats). The authors identified three ways of managing online reputation: measuring, monitoring and participating in an ongoing process. However, Jones et al. (2009b) stated that, since a firm is highly exposed, results are best achieved with a maximum degree of transparency (internally and externally).

Moreover, the Web 2.0 has given access to new forms of information, through the concept of "Big Data". The use of structured and unstructured data has made possible the emergence of a new proxy and new variables to capture complex situations, as well as new ways of measuring risks. Authors have used information posted on social websites in order to invest on the stock markets using Twitter messages (Bollen et al., 2011; Mao et al., 2011). Based on a pure popularity approach, O'Connor (2013) explores the relation between fan counts of popular brands on Facebook and a construct of (1) consumer following, (2) signaling concurrent changes in brand performance, and (3) valuations of brand companies on the stock markets.

With more exposure comes also a different approach on how to handle a crisis. One simple answer to crisis could be characterized by fast action. SCCT (Situational Crisis Communication Theory) has given a framework to approach this situation (Coombs, 2007). "A crisis is a sudden and unexpected event that threatens to disrupt an organization's operations and poses both a financial and a reputational threat," says the author, whereas "crises threaten to damage reputations because a crisis gives people reasons to think badly of the organization." This is especially true in the present social media era. Coombs suggests that three factors shape the reputational threat: the initial crisis responsibility, the crisis history of the company 
and the prior relational reputation; the last two factors being seen as aggravating or reducing factors to the reputational threat. Dawar and Pillutla (2000) suggested that the way firms can handle a product-harm crisis is determinant in terms of impact on their brand. An ambiguous response could worsen a threat from the public's point of view.

In a publication of the Web Ecology Project (Leavitt et al., 2009), the process of influence on social media, such as Twitter, is to be considered different from usual media. In fact, the free and unfiltered information flows not only in a one-way direction, but also in a network scheme, giving an individual the opportunity to express himself. Since everyone is able to comment, share and publish information, a firm is more than ever exposed to viral content.

Analogy with the biological world can easily express the behavior of viral marketing. Viruses need hosts to be spread. In fact, an epidemic disease occurs when the number of infected cases exceeds the expected scenarios of endemic behavior (low and constant propagation). The network connections between subjects contribute to this fast transmission of viruses (Prescott et al., 2002). To go viral occurs when content and information are spread in the same network pattern between users on the Internet.

One question that can be addressed is: how and why does content become viral? As part of a viral marketing strategy, several elements have to be taken into account: providing effortless transfer to others, easy scaling from small to large size, use of existing communication networks and taking advantage of others' resources (Wilson, 2000, cited by Jatin et al., 2012). These factors are in fact all common to social media networks, where constant and fast connectivity between users is unavoidable.

Analyzing a data set of articles published in the New York Times, Berger et al. (2009) try to understand how the content of a message can affect its virality. With a psychological approach, they show that content that evokes high-arousal emotions is more likely to be viral (both positive or negative: awe, anger, anxiety). This can be closely linked to the success of meme websites: by clustering emotions, users have access to highly addictive content that is generated continuously by the community.

Authors have seen the opportunities that can bring a viral communication strategy. For Moore (2003), the strong benefit of viral marketing is that every user or consumer can be used as an 'involuntary salesperson' (just like hosts for viruses). Examples of how fast Hotmail, Yahoo! or Gmail accounts were opened illustrate this opportunity. More recently, Psy's YouTube video (Gangnam Style) has gained huge exposure, after being seen more than 1.6 billion times in only 10 months. Larcker et al. (2012) view social media as an opportunity for firms to directly access their reputational risks. In fact, monitoring the social websites, such as Twitter (Jansen et al., 2009), YouTube or Facebook, has given signs of effective early warnings: Eli Lilly, Nestlé, Procter \& Gamble, Burger King are among the companies that have either approached social media as a monitoring tool or been harmed by scandals spread on these media, highlighting the importance of corporate reputation in a social media era.

\section{The model}

We propose a game theoretical approach to analyze the determinants of reputation. Based on this model, we will be able to define concepts such as reaction time, recovery time, and level of reputation. These concepts will help us understand the specificities of each firm's reputation. We will use these concepts to categorize companies and, therefore, we will be able to evaluate the impact of an adverse event on a company's reputation.

The game theoretical approach will also help us design the best strategic responses to an adverse event, and the timing of the responses. 
The model is a signaling model specifically designed to fit the social media context. The model is built with two players: the firm and the social media users (consumers or people who believe they are stakeholders). The firm will send signals about its activities and the social media users will respond or not to these signals. We are able to devise multiple equilibriums and a Pareto-optimal solution depending on the reaction time of the company and its initial level of reputation.

\subsection{The structural equation}

Based on the previous definitions, there is a relationship between the concept of reputation and the concept of brand. In particular, this relationship will depend on three sub-definitions of brand: (1) brand positioning, (2) brand re-positioning, and (3) brand de-positioning (Maggard, 1976). Reputation will thus be defined considering these three subtleties. We also add another important dimension: reputation has a temporal aspect, while branding is assessed in a relative way. Branding is indeed defined relatively to the other brands in the same industry. This is where the three aforementioned definitions of positioning, repositioning and de-positioning are much relevant. They provide a dynamic perspective, considering the strategies within an industry, and we capture the impact on the concept of reputation of this dynamics by introducing a temporal dimension. We also assume positioning/re-positioning/de-positioning are relative concepts, inherently linked to the dynamics of the industry, thus we consider the difference in the change of the brand level for each company.

Let us define the structural equation, assuming two firms in the industry, represented by the subscripts $a$ and $b$ :

$$
r_{a, t}-r_{a, t-1}=\alpha_{a, t} \cdot\left(\Delta b_{a, t}-\Delta b_{b, t}\right)+\varepsilon_{a, t}||\{a, b\}|a=1,2| b=1,2 \mid a \neq b
$$

where $\Delta r$ represents the change in reputation. Reputation is thus assumed to have a temporal dimension. $\Delta b$ represents the change in brand perception and is considered here relatively to the industry. $\mathcal{E}_{a, t}$ represents an external event impacting the firm's reputation.

We have three possibilities in our information set for the dynamics of reputation:

$$
I_{t}=\left\{E_{1}=\left(\Delta b_{a, t}-\Delta b_{b, t}=0\right), E_{2}=\left(\Delta b_{a, t}-\Delta b_{b, t}>0\right), E_{3}=\left(\Delta b_{a, t}-\Delta b_{b, t}<0\right)\right\}
$$

with $E$ representing the three different events.

\subsection{The players}

The game will be played between two types of players: a firm and the social media users. The payoff for the firm increases with a higher reputation and decreases with de-positioning $\left(I_{t}=E_{3}\right)$ vis-à-vis the competition in the industry. The social media users (SMU) receive a payoff every time they promote their opinion or relay someone else's opinion. We assume a linear relationship between their payoff and their opinion. We also assume zero cost, considering they are already connected to the Internet and the various social media.

The payment function for the firm will be represented by the following profit function, which will be defined as the sum of the tangible $\mathrm{T}_{n}$ and intangible values $r_{n, t}$ : 


$$
\Pi_{n, t}=\mathrm{T}_{n, t}+r_{n, t}
$$

Since the goal of this paper is to assess the impact of an adverse event on a firm's reputation, we will focus on the loss in intangible value of the firm following a buzz in social media. We will thus consider one of the sub-games specifically capturing the loss in intangible value, i.e. when $\beta<0$ with $\beta=f(\varepsilon)$.

The loss in the intangible value, represented by the intangible value, is:

$$
\Lambda_{\text {firm }, t}=\left(\rho_{\text {firm,t }}\right)^{2}+\chi \cdot\left(\beta+\phi \cdot\left(\rho_{\text {smu }, t}-\rho_{\text {firm }, t}\right)\right)^{2}
$$

where $\rho_{\text {firm,t }}$ represents the response of the firm impacted by the adverse event and $\rho_{\text {smu,t }}$ represents the response from the consumers/civil society through social media/buzz.

\subsection{The strategies}

For each player, there will be two strategies $S \subseteq S$ in this sub-game:

$$
S \subseteq S \mid S=\left\{\begin{array}{l}
S_{1}=\left(S_{1, \text { firm }, t} \cup S_{1, \text { smu }, t}\right), S_{2}=\left(S_{1, \text { firm }, t} \cup S_{2, \text { smu }, t}\right), \\
S_{3}=\left(S_{2, \text { firm }, t} \cup S_{1, \text { smu }, t}\right), S_{4}=\left(S_{2, \text { firm }, t} \cup S_{2, \text { smu }, t}\right)
\end{array}\right\}
$$

For the firm, there will be two strategies: coordination and non-coordination. With $n=\{$ firm, smu $\}$, the first strategy $S_{1, n, t}$ corresponds to coordination. The second strategy $S_{2, n, t}$ corresponds to noncoordination. Coordination means that when an adverse event happens, the civil society and the firm do not make a big fuss about it. In other words, the civil society has a high level of confidence in the firm's management and communication about the adverse event. Non-coordination means that (1) the civil society does not trust the firm and, as a consequence, does not believe in the firm's response, or decides to augment the buzz, and that (2) the firm, when it plays non-coordination, does not trust the civil society.

The payoff function is the result of the strategies played by the players, with $\Lambda_{\text {firm,t }}=f(S)$.

In this strategic context, equation (4) can be rewritten as:

$$
\Lambda_{\text {firm }, t}=\left(\rho_{\text {firm }, t}\right)^{2}+\chi \cdot\left(\beta+\phi \cdot\left(\rho_{\text {smu }, t}-\rho_{\text {firm }, t}\right)\right)^{2}
$$

We only consider the payment function of the firm since we assume the SMU's payment function is a simple linear transformation.

\section{Strategies in the context of a repeated game with a finite horizon}

\subsection{The model under $S$}


Let us first start with the information set defined as $\mathbf{S}$. In this context, both players will play a strategy of coordination, meaning $\rho_{\text {firm }, t}=\rho_{\text {smu }, t}$. We will also assume that $\rho_{\text {firm }, t}=\rho_{\text {smu }, t}=0$. It simplifies the model without changing anything to the interpretation of the results. Equation (6) can be rewritten as:

$$
\Lambda_{n, t}=\chi \cdot \beta^{2}
$$

\subsection{The model under $S_{4}$}

Let us now move to the information set $S_{4}$. In this context, the firm will want to minimize its loss, without considering the other player. The firm will play discretionarily, and the social media users know it. The way the firm will respond to an adverse event will depend on $\beta$ (a function of the adverse event), but also on the level of awareness of the firm vis-à-vis its reputation (captured by $\chi$ and $\phi$ ).

Equation (6) can be minimized:

$$
\frac{\partial \Lambda_{\text {firm }, t}}{\partial \rho_{\text {firm }, t}}=\frac{\partial\left(\left(\rho_{\text {firm }, t}\right)^{2}+\chi \cdot\left(\beta+\phi \cdot\left(\rho_{\text {smu }, t}-\rho_{\text {firm }, t}\right)\right)^{2}\right)}{\partial \rho_{\text {firm }, t}}=0
$$

Leading to:

$$
\rho_{\text {firm }, t}=\frac{\chi \cdot \phi \cdot\left(\beta+\phi \cdot \rho_{\text {smu }, t}\right)}{1+\chi \cdot \phi^{2}}
$$

To solve this function, and considering the information set in which we are, we assume that the SMU are well aware of this minimization program, and thus will anticipate:

$$
\rho_{\text {smu }, t}=\frac{\chi \cdot \phi \cdot\left(\beta+\phi \cdot \rho_{\text {firm,t }}\right)}{1+\chi \cdot \phi^{2}}
$$

As a result:

$$
\rho_{\text {firm }, t}=\rho_{\text {smu }, t}=\chi \cdot \phi \cdot \beta
$$

By substituting equation (11) into equation (6), the loss function for the firm is then:

$$
\Lambda_{\text {firm }, t}=\beta^{2} \cdot\left(\chi+\chi^{2} \cdot \phi^{2}\right)
$$

\subsection{The model under $S_{2}, S_{3}$}


These payoffs ( $\mathrm{S} 2$ and $\mathrm{S} 3$ ) correspond to the situation where one player plays coordination and the other one plays non-coordination $\left\{S_{2}=\left(S_{1, \text { firm,t }} \cup S_{2, \text { smu }, t}\right), S_{3}=\left(S_{2, \text { firm,t }} \cup S_{1, \text { smu }, t}\right)\right\}$.

The loss function becomes:

$$
\Lambda_{\text {firm,t }}=\left(\rho_{\text {firm, },}\right)^{2}+\chi \cdot\left(\beta+\phi \cdot\left(-\rho_{\text {firm }, t}\right)\right)^{2}
$$

It can be minimized, leading to:

$$
\rho_{\text {firm }, t}=\frac{\chi \cdot \phi \cdot \beta}{1+\chi \cdot \phi^{2}}
$$

By substituting equation (14) into equation (13), we obtain:

$$
\Lambda_{\text {firm }, t}=\frac{\chi \cdot \beta^{2}}{1+\chi \cdot \phi^{2}}
$$

The solution of the game is thus a Nash equilibrium captured by $S_{4}$, although the Pareto-optimal equilibrium is $S\left(S \succ S_{4}\right)$. In this sub-game with a finite horizon, a high reputation of transparency and honesty of a firm may play a triggering effect leading to $S_{1}$.

\section{Strategies in the context of a repeated game with an infinite horizon}

\subsection{Dynamics of the game}

Here is the sequencing of the decision process:

Step 1. Initially, the players begin with $\rho_{\text {firm,t }}=\rho_{\text {smu }, t}=0$, hence $\Lambda_{\text {firm }, t}=\chi \cdot \beta^{2}$.

Step 2. Then, an adverse effect occurs. The firm decides to play non-coordination: $\rho_{\text {firm,t }}=\chi \cdot \phi \cdot \beta / 1+\chi \cdot \phi^{2}$. During the first period, the firm will then benefit:

$$
\left\{\left(\Lambda_{\text {firm }, t} \mid S_{1}\right)-\left(\Lambda_{\text {firm }, t} \mid S_{2}\right)\right\}=\chi \cdot \beta^{2}-\frac{\chi \cdot \beta^{2}}{1+\chi \cdot \phi^{2}}=\frac{\chi^{2} \cdot \phi^{2} \cdot \beta^{2}}{1+\chi \cdot \phi^{2}}
$$

Step 3. But then, the SMU will change their strategy and play $S_{2}$. Therefore, $\rho_{\text {firm }, t}=\rho_{\text {smu }, t}=\chi \cdot \phi \cdot \beta>0$, leading to:

$$
\left\{\left(\Lambda_{\text {firm }, t} \mid S_{4}\right)-\left(\Lambda_{\text {firm, } t} \mid S\right)\right\}=\beta^{2} \cdot\left(\chi+\chi^{2} \cdot \phi^{2}\right)-\chi \cdot \beta^{2}=\chi^{2} \cdot \phi^{2} \cdot \beta^{2}
$$


Step 4. This case of non-coordination will last for $T$ periods, after which the Pareto-optimal equilibrium will be played again.

\subsection{Conditions for coordination}

A firm will want to invest in its reputation so long as:

$$
\left\{\left(\Lambda_{\text {firm }, t} \mid S\right)-\left(\Lambda_{\text {firm }, t} \mid S_{2}\right)\right\}<\sum_{t=1}^{T} \delta^{t} \cdot\left\{\left(\Lambda_{\text {firm }, t} \mid S_{4}\right)-\left(\Lambda_{\text {firm }, t} \mid S\right)\right\}
$$

where $\delta=(1+R)^{-1}<1$ is the discount factor. It captures the time preference of the firm. The higher the reputation of the firm, the lower the discount factor. Equation (18) can be rewritten:

$$
\frac{\chi^{2} \cdot \phi^{2} \cdot \beta^{2}}{1+\chi \cdot \phi^{2}}<\sum_{t=1}^{T} \delta^{t} \cdot \chi^{2} \cdot \phi^{2} \cdot \beta^{2}
$$

therefore:

$$
\frac{1}{1+\chi \cdot \phi^{2}}<\frac{\delta \cdot\left(1-\delta^{T}\right)}{1-\delta}
$$

Let us define $k(T, \delta)=\delta \cdot\left(1-\delta^{T}\right) / 1-\delta$ with $k(1, \delta)=\delta$ and $\{\partial k / \partial T>0 ; \partial k / \partial \delta>0\}$. Thus, equation (20) becomes:

$$
\frac{1}{1+\chi \cdot \phi^{2}}<k(T, \delta)
$$

\subsection{Implications for the role of reputation and the strategies to develop in case of an adverse event}

There is $\hat{T}$ representing the duration for which a firm is indifferent between coordination and noncoordination. This duration is represented by:

$$
\frac{1}{1+\chi \cdot \phi^{2}}=k(\hat{T}, \delta)
$$

- with $\forall T>\hat{T}$, the discounted loss is greater than the benefit from choosing $S_{2}$ or $S_{3}$, therefore the non-coordination strategy will not be chosen by a rational firm.

- or with $\forall T>\hat{T}$, the discounted loss is lower than the benefit from choosing $S_{2}$ or $S_{3}$, therefore the coordination strategy will not be chosen by a rational firm.

The following figure allows us to easily visualize equation (22) and this condition. We have represented a straight line $k(T, \delta)$ when $T=0$, then $\delta$ captures the initial level of reputation awareness. 
Then, the immediate benefit from the non-coordination strategy for the firm is, by definition, time invariant (independent from $\mathrm{T}$ ) and is captured by a horizontal line $y=\frac{1}{1+\chi \cdot \phi^{2}}$, $\forall \chi \in[0, \infty] \Leftrightarrow y \in[1,0[$

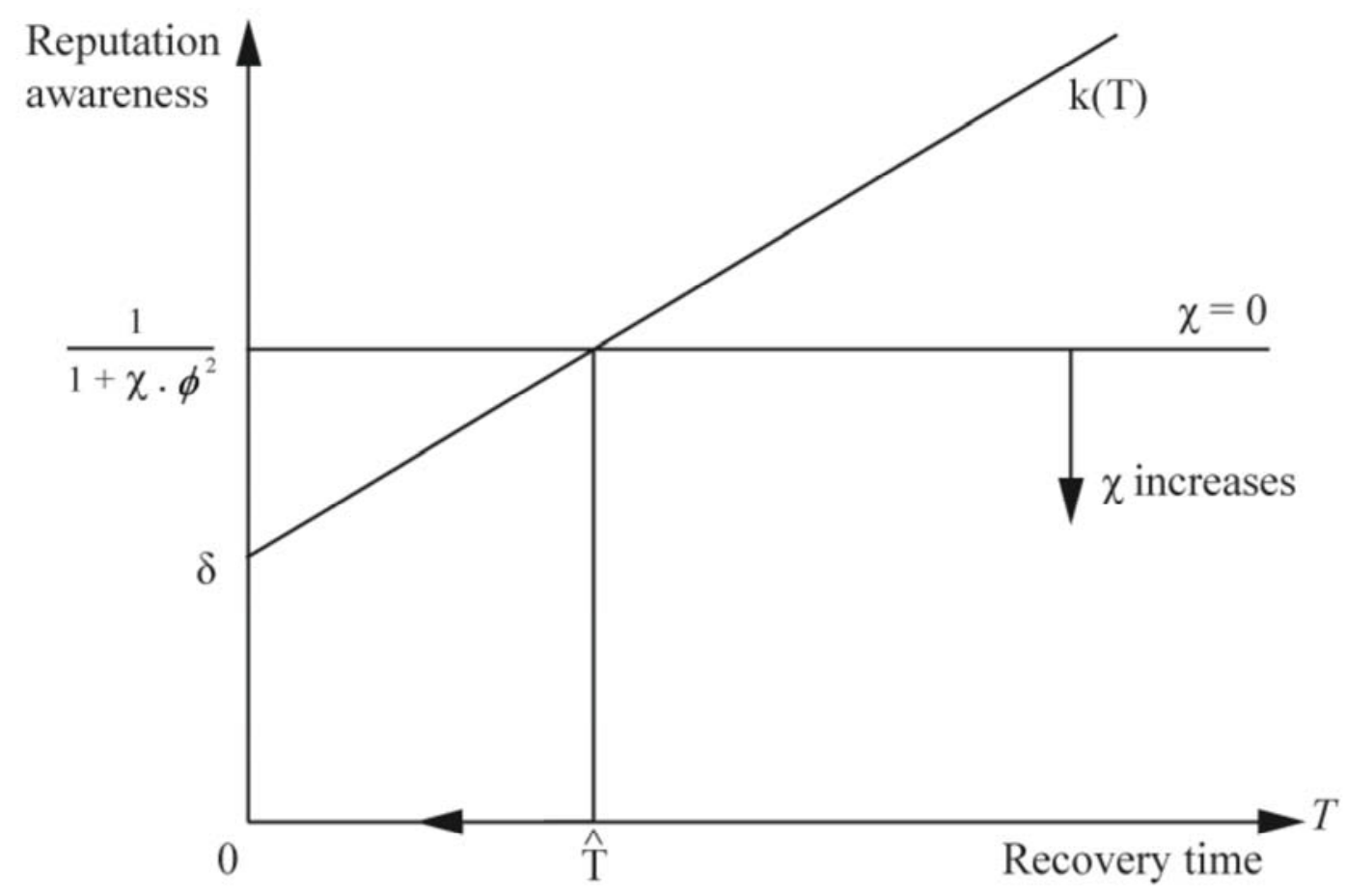

Figure 1. Best strategic responses.

The interpretation of this figure is interesting in terms of the best strategic responses based on the initial conditions of the firm:

1. If the duration of the non-coordination strategies is long enough and beyond a certain limit, then the coordination strategy is preferred. In a nutshell, a high level of reputation is always desirable. This is the mathematical proof of why reputation - the intangible value of the firm - is one of its best assets.

2. The non-coordination solution $S_{4}$ could be chosen, but only when the duration of the game is very short, for instance in the finite horizon game.

3. The minimal duration of the non-coordination strategies $(\hat{T})$ is a decreasing function of $\chi$.

4. There exists a critical value of $\chi$ beyond which coordination is preferred, even in the short term. More precisely,

$\forall \chi>R / \phi^{2},\left\{\left(\Lambda_{\text {firm }, t} \mid S\right)-\left(\Lambda_{\text {firm }, t} \mid S_{2}\right)\right\}<\sum_{t=1}^{T} \delta^{t} \cdot\left\{\left(\Lambda_{\text {firm }, t} \mid S_{4}\right)-\left(\Lambda_{\text {firm }, t} \mid S\right)\right\} \mid T=1$.

5. Ceteris paribus, the duration of the non-coordination strategies increases when the discount factor $\delta$ decreases. 


\section{Conclusion}

This model, and discussion around it, is a first attempt to put together different definitions such as reputation, branding, etc. It is also a first attempt to model and represent mathematically what the concept of reputation entails. Indeed, the notion of reputation is often defined as an intangible asset for firms. Intangible implies that we cannot measure it. However, the financial impact of a good (bad) reputation is real, but also difficult to measure. In a firm's accounting books, we find all the tangible assets, whereas the intangible assets - and reputation for that matter - are approximated by the financial world and embodied in the stock price when the company is public. The volatility of the stock price is often related to perceptions from the financial market, and reputation is an important aspect of this volatility. In short, what we have in this paper is an attempt to model and thus capture in a tangible way what reputation means.

This is even more interesting in the context of social media. In a nutshell, social media have changed the customer's loyalty paradigm. As aforementioned, information can be (1) a true fact or it can be (2) a pure hoax, and on top of that, the nature of the informant has also changed: a brand can be attacked by a foreign citizen who does not even have access to the firm's product or service.

The conclusions from our model are clear. The possibility of facing a buzz on top of the direct consequences of an adverse effect leads to the idea that a firm should always try to prevent the buzz and put together a communication system that will respond to the buzz. Here, the buzz is proven to be a dominant strategy, thus highly credible.

Another result is that coordination is in fact the spontaneous strategy for a firm if it wants to reduce its response costs when facing an adverse event. In other words, it is always profitable for a firm to invest in a high-level reputation. Otherwise, when a firm does not give too much attention to its reputation (low level

of reputation awareness), then $\delta$ is low. In this situation, in case of an adverse event, the recovery time to the initial level of reputation will be greater.

For further research, we hope this paper opens the door to more questions and approaches. For instance, it would be interesting to design a model for the demand side (the SMU) in addition to the supply side (the firm or the industry). 


\section{References}

Bennett, Lance. 2003. "New Media Power: The Internet and Global Activism.” In Contesting Media Power: Alternative Media in a Networked World, 17-37. Lanham: Rowman \& Littlefield.

Berger, Jonah, and Katherine Milkman. 2009. "What Makes Online Content Viral?” SSRN Scholarly Paper ID 1528077. Rochester, NY: Social Science Research Network. http://papers.ssrn.com/abstract=1528077.

Bollen, Johan, Huina Mao, and Xiao-Jun Zeng. 2011. “Twitter Mood Predicts the Stock Market.” Journal of Computational Science (March): Pages 1-8. doi:10.1016/j.jocs.2010.12.007.

Brammer, Stephen, and Stephen Pavelin. 2004. "Building a Good Reputation." European Management Journal 22 (6) (December): 704-713. doi:10.1016/j.emj.2004.09.033.

Bromley, Dennis Basil. 1993. Reputation, Image and Impression Management. Vol. viii. Oxford, England: John Wiley \& Sons.

Cabral, Luis M. B. 2000. "Stretching Firm and Brand Reputation." The RAND Journal of Economics 31 (4): 658. doi:10.2307/2696353.

Choi, Jay Pil, and Doh-Shin Jeon. 2007. "A Leverage Theory of Reputation Building with Co-branding: Complementarity in Reputation Building." http://repositori.upf.edu/handle/10230/460.

Chun, Rosa. 2005. "Corporate Reputation: Meaning and Measurement." International Journal of Management Reviews 7 (2): 91-109. doi:10.1111/j.1468-2370.2005.00109.x.

Coombs, W. T. 2007. "Protecting Organization Reputations During a Crisis: The Development and Application of Situational Crisis Communication Theory." Corporate Reputation Review 10 (3): 163-176.

Dawar, N., and M. M. Pillutla. 2000. "Impact of Product-harm Crises on Brand Equity: The Moderating Role of Consumer Expectations.” Journal of Marketing Research: 215-226.

De Marcellis-Warin, Nathalie, and Serban Teodoresco. 2012. "Corporate Reputation: Is Your Most Strategic Asset at Risk?” CIRANO Burgundy Report 2012RB-02 (April).

Dröge, Cornelia, and Rene Y. Darmon. 1987. "Associative Positioning Strategies through Comparative Advertising: Attribute Versus Overall Similarity Approaches.” Journal of Marketing Research: 377-388.

Fombrun, C. J., and CBM van Riel. 1997. "The Reputational Landscape." Corporate Reputation Review 1 (2) (July 1): 5-13. doi:10.1057/palgrave.crr.1540024.

Fombrun, Charles J. 1996. Reputation: Realizing Value from the Corporate Image. Harvard Business Press.

Fudenberg, Drew, and David M. Kreps. 1986. "Reputation and Multiple Opponents I: Identical Entrants". Department of Economics, Working Paper Series qt2cs887vq. Department of Economics, Institute for Business and Economic Research, UC Berkeley. http://ideas.repec.org/p/cdl/econwp/qt2cs887vq.html.

Jansen, Bernard J., Mimi Zhang, Kate Sobel, and Abdur Chowdury. 2009. "Twitter Power: Tweets as Electronic Word of Mouth.” Journal of the American Society for Information Science and Technology 60 (11): 2169-2188. doi:10.1002/asi.21149.

Jatin, Pandey, R. Sunaina, and Sundar Anupama. "A Study on Factors Affecting the Exposure to Viral Marketing Messages.” International Journal of Management \& Business Studies: 2012. 
Jones, Brian, Ryan Bowd, and Ralph Tench. 2009. "Corporate Irresponsibility and Corporate Social Responsibility: Competing Realities." Social Responsibility Journal 5 (3) (July 31): 300-310. doi:10.1108/17471110910977249.

Jones, Brian, John Temperley, and Anderson Lima. 2009. "Corporate Reputation in the Era of Web 2.0: The Case of Primark." Journal of Marketing Management 25 (9-10): 927-939. doi:10.1362/026725709X479309.

Keller, Kevin Lane, and Donald R. Lehmann. 2006. "Brands and Branding: Research Findings and Future Priorities.” Marketing Science 25 (6) (November 1): 740-759. doi:10.1287/mksc.1050.0153.

Knox, Simon, and David Bickerton. 2003. "The Six Conventions of Corporate Branding." European Journal of Marketing 37 (7/8): 998-1016.

Kreps, David M, Paul Milgrom, John Roberts, and Robert Wilson. 1982. "Rational Cooperation in the Finitely Repeated Prisoners' Dilemma.” Journal of Economic Theory 27 (2) (August): 245-252. doi:10.1016/0022-0531(82)90029-1.

Kreps, David, and Robert Wilson. 1981. “Reputation and Imperfect Information”. Levine’s Working Paper Archive 238. David K. Levine. http://ideas.repec.org/p/cla/levarc/238.html.

Larcker, David, Sarah Larcker, and Brian Tayan. 2012. "Monitoring Risks Before They Go Viral: Is It Time for the Board to Embrace Social Media?" SSRN Scholarly Paper ID 2035072. Rochester, NY: Social Science Research Network. http://papers.ssrn.com/abstract=2035072.

Leavitt, Alex, Evan Burchard, David Fisher, and Sam Gilbert. 2009. "The Influentials: New Approaches for Analyzing Influence on Twitter.” http://www.webecologyproject.org/wpcontent/uploads/2009/09/influence-report-final.pdf.

Maggard, John P. 1976. “Positioning Revisited.” The Journal of Marketing 40 (1): 63-66.

Mailath, George. 2007. "Reputation Effects". SSRN Scholarly Paper ID 1023658. Rochester, NY: Social Science Research Network. http://papers.ssrn.com/abstract=1023658.

Mao, Huina, Scott Counts, and Johan Bollen. 2011. "Predicting Financial Markets: Comparing Survey, News, Twitter and Search Engine Data." arXiv:1 112.1051 (December 5). http://arxiv.org/abs/1112.1051.

Mei, Joanna Siah Ann, Namrata Bansal, and Augustine Pang. 2010. "New Media: a New Medium in Escalating Crises?” Corporate Communications: An International Journal 15 (2) (May 11): 143-155. doi:10.1108/13563281011037919.

Milgrom, Paul R. 1981. "Rational Expectations, Information Acquisition, and Competitive Bidding." Econometrica 49 (4): 921-43.

Milgrom, Paul, and John Roberts. 1981. "Predation, Reputation , and Entry Deterrence”. Levine's Working Paper Archive 1460. David K. Levine. http://ideas.repec.org/p/cla/levarc/1460.html.

Moore, Robert E. 2003. "From Genericide to Viral Marketing: On 'brand'.” Language E' Communication 23 (3-4) (July): 331-357. doi:10.1016/So271-5309(03)00017-X.

O'Connor, Arthur J. 2013. "The Power of Popularity An Empirical Study of the Relationship Between Social Media Fan Counts and Brand Company Stock Prices." Social Science Computer Review 31 (2) (April 1): 229-235. doi:10.1177/0894439312448037. 
Park, C. Whan, Bernard J. Jaworski, and Deborah J. Maclnnis. 1986. "Strategic Brand Concept-image Management." The Journal of Marketing: 135-145.

Porter, L., and G. J. Golan. 2006. "From Subservient Chickens to Brawny Men: A Comparison of Ciral Advertising to Television Advertising." Journal of Interactive Advertising.

Prescott, Harley, and Klein. 2003. Microbiology. 5th edition. De Boeck.

Rodrigues, Flavio, Victoria Souza, and Joao Leitao. 2009. "Strategic Coopetition of Global Brands: A Game Theory Approach to 'Nike + iPod Sport Kit' Co-branding - Munich Personal RePEc Archive." http://mpra.ub.uni-muenchen.de/16146/1/MPRA_paper_16146.pdf.

Sanger, William, Bertrand Nembot, and Thierry Warin. 2013. "Bull, Bear, and the Blue Bird." Polytechnique Montreal \& CIRANO.

Selten, Reinhard. 1974. “The Chain Store Paradox”. Working Paper 018. Bielefeld University, Center for Mathematical Economics. http://ideas.repec.org/p/bie/wpaper/o18.html.

Stavrakantonakis, I., A. E. Gagiu, H. Kasper, I. Toma, and A. Thalhammer. 2012. "An Approach for Evaluation of Social Media Monitoring Tools." Common Value Management: 52.

Veil, Shari R., Timothy L. Sellnow, and Elizabeth L. Petrun. 2011. "Hoaxes and the Paradoxical Challenges of Restoring Legitimacy: Dominos' Response to Its YouTube Crisis." Management Communication Quarterly (December 4). doi:10.1177/0893318911426685. http://mcq.sagepub.com/content/early/2011/11/18/0893318911426685. 